\title{
European Imbalances: The Sound and the Fury
}

\author{
Jérôme Creel
}

\section{Introduction}

The European crisis has gathered much attention. The double-dip recession and then the slow recovery process have shaken the European process of economic and monetary integration and even raised doubts on the survival of the Euro, the single currency of 19 out of 28 member states of the European Union (EU). The Brexit decision taken by the British citizens and their government in 2016 followed by the Catalan crisis in Spain in 2017 are the visible political parts of the iceberg that hit the EU. Threats to the European process, via relatively bad economic performance, have generated many explanations, some exclusive, some interrelated.

The first objective of this chapter is to review these explanations in a critical manner. The second objective is to draw a comprehensive view about European economic difficulties - I will call them European imbalances-and discuss different policy strategies to fix them.

Two forewords are important at this stage. First, the chapter will deal explicitly neither with political issues - they are implicitly involved in the different explanations-nor with the political feasibility of reforms. Consequently, some of the reforms I will evoke here can be thought as directions for reforms rather than reforms per se. Second, the directions for reforms presented here are the outcome of a larger

This contribution draws on the keynote speech I prepared for the conference Strategica organized by the Faculty of Management from the National University of Political Studies and Public Administration (SNSPA) and the Romanian Academic Society of Management (SAMRO) with the support of the National Bank of Romania, in Bucharest in September 2017. I thank the participants and an anonymous referee for their remarks and George Papaconstantinou for his insightful comments.

J. Creel $(\bowtie)$

Observatoire français des conjonctures économiques (OFCE, Sciences Po), Paris, France

e-mail: jerome.creel@ sciencespo.fr 
project, the independent Annual Growth Survey (iAGS), to which I will refer in due course.

The title, in reference to the novel by William Faulkner, The sound and the fury (Jonathan Cape and Harrison Smith Publisher, 1929), may seem weird in a volume of economics and statistics. Nevertheless, the different narratives of the European crisis mirror the different levels of consciousness of the narrators in the novel. In it, we read the story of the Compson family and its fall through the eyes of the three brothers: Benjy, the disabled, Quentin, the intelligent, and Jason, the cynical; before a neutral and external narrator takes the lead and focuses on Dilsey, the servant. Thus, there are four different views in the book: a flawed one by Benjy, a disastrous one by Quentin, a cynical one by Jason, and an omniscient view by an external narrator. The latest view is the most comprehensive as it depicts the Compson family's story without embracing an intimate feeling.

The following will draw on these four views. The first part will deal with the flawed view according to which imbalances in public finances generated the European crisis. Although it has not been stated that bluntly, the recommendations which followed the European crisis are consistent with this view. The second part will relate the European crisis to a balance-of-payment crisis, a disastrous view. The third part will discuss labor market issues and nominal and real divergence across the Eurozone member states. I label this view a cynical view. The fourth part will adopt a comprehensive view: fiscal and current account imbalances are related and feed divergence. Finally, fixing these imbalances requires a comprehensive agenda for reforms on the fiscal side, but not only. Against this backdrop, I will discuss the recent reform proposals. Moreover, I will briefly argue that symmetric cooperation should prove important in delivering an optimal Eurozone.

Before presenting these views, let me briefly sketch the imbalances. Under a macroeconomic perspective, there are at least three main imbalances in the Eurozone. The first one is certainly the unemployment situation and, with it, the growth situation. In 2016, the unemployment rate reached $10 \%$ of the labor force in the Eurozone, and $9.4 \%$ in the EU. Though it has decreased after peaking at, respectively, 12 and $11 \%$ in 2013 in the Eurozone and the EU, the unemployment rate remains high-it is still, respectively, 2.5 and $1.5 \%$ points above its lowest in 2008-and it fuels income, social, and geographical inequalities across regions and countries. The second imbalance relates to public finances. Since 2007, the ratio of public debt to GDP has increased by $25 \%$ points in the Eurozone following the large deficits that governments accumulated to dampen the global financial crisis (GFC). The third imbalance is the large current account surplus of the Eurozone vis-à-vis the rest of the world. In 2015, the Eurozone had a current account surplus of $3 \%$ of its GDP.

Against the backdrop of these imbalances, the economic performance of the EU and the Eurozone remains subdued. Figure 1 shows the evolution of the GDP growth rate since the birth of the euro in 1999. It is striking that the average between 1999 and 2007 is still higher than the recent data (2015 and 2016) despite the sharp recession of 2009 and the recession of 2012-2013. This is evidence of a slow recovery. 




Fig. 1 Eurozone and EU GDP growth rate (in \%). Source: Eurostat https://ec.europa.eu/eurostat/fr/ home, date of access 20 September 2017

Another piece of evidence is the inflation rate. Although the European Central Bank has been implementing an expansionary monetary policy since March 2015 through massive purchases of public sector bonds, the consumer price index (including the prices of volatile materials like oil) has been almost continuously moving below the target of close to $2 \%$. In September 2017, the inflation rate lay at $1.5 \%$. Last, the slowdown in labor productivity has been quite substantial in the Eurozone and in the EU, from an average growth rate of $1.3 \%$ and $1.8 \%$ for the Eurozone and the EU, respectively, between 1999 and 2007 to an average of $0.8 \%$ for both since 2008 (source: OECD).

\section{The Flawed View}

The European sequel of the GFC has been frequently labelled a "European sovereign debt crisis". Checking on Google Scholar gives almost 300,000 results. The paper by P. Lane (2012) published under this title has been cited more than 700 times since 2012.

P. Lane does not attribute the European crisis explicitly to public debt issues and he argues for comprehensive EU reforms beyond fiscal policy, like the endorsement of a banking union. That said, the very choice of the label, "sovereign debt crisis", gives a clear idea of the culprit: governments.

There have been three phases in the evolution of public debt since 1999. First, before the GFC, debts were not high on average but there were substantial differences between Germany, France, and Spain, on the one hand, and Greece, Italy, and Portugal on the other hand. These differences fueled idiosyncratic fiscal risks in the Eurozone, between a core with stable or declining debt-to-GDP ratios and a periphery with growing debts. The onset of the crisis led to sharp increases in public debt in all Eurozone countries, giving way to the second phase. It also led to a break in the 
fulfilment of the European fiscal rules, the so-called Stability and Growth Pact (SGP). Ireland and Greece showed public deficits well above the threshold at 3\% of GDP in 2009, respectively, at $13 \%$ and $15 \%$ of GDP, and the Irish deficit was at $32 \%$ of GDP in 2010 after accounting for the nationalization of banks. The surge of public debts and deficits after the GFC would have precipitated Eurozone countries into a new crisis for two reasons: first, it highlighted that the economic governance of the Eurozone was flawed since the very beginning because national fiscal policies shared a heavier burden for stabilization in the absence of a fiscal union to complement the monetary union (Wyplosz 1997); second, fiscal policies which produced high deficits and debts were not effective at stabilizing the economy. Under what was only an assumption-fiscal policy is not effective at stabilizing the economythe cure to the so-called "sovereign debt crisis" was easy to find: fiscal austerity. Large public deficits hence initiated a third phase of radical change in fiscal policy with the implementation of consolidation measures and fiscal austerity.

More than a flaw of economic governance-it could have been overturned by the coordination of fiscal policies under some discretion (Creel and Sterdyniak 1998) the view according to which the European crisis is related to "sovereign debts" reveals a long-lasting reluctance for the use of fiscal policy. This is clearly visible in the economic governance which has settled: a dominant independent central bank that sets the common interest rate and national governments facing fiscal limitations. The central banker is supposed to steer the Eurozone economy into a steady state and is protected from the negative spillovers of supposedly lax fiscal policies.

Where did this view on fiscal policy originate? The answer is quite certainly in the fallacy that fiscal contraction proves expansionary (Giavazzi and Pagano 1990, called it a "tale" but were very influential at using it to be critical of active fiscal policies) ${ }^{1}$ and also in the application of "rational expectations" in general equilibrium macro models. In a world without frictions, like price and wage rigidities, and under "rational expectations", tax and fiscal discretion mainly add noise and biases to the economy. They destabilize rather than stabilize it. The optimal policy is thus characterized by a stable and easily expected policy, hence the fiscal rules.

In a different framework, with frictions and in the presence of demand-driven unemployment, tax and fiscal policies have very different outcomes. ${ }^{2}$ The choice of fiscal policy is therefore a matter of economic conditions, and so is its real effectiveness. It is not a minor paradox that the economist who restored the "fiscal multiplier effect" is the same economist who acted as the IMF chief economist during the so-called sovereign debt crisis. Indeed, O. Blanchard, with R. Perotti, renewed interest in fiscal policy in 2002 with the publication of a paper that concluded that the fiscal multiplier, i.e. the impact of a change in fiscal policy on real output, had been positive and slightly above unity in the US since the early 1950s. This work has been applied to many other countries by many other economists (e.g. Creel et al. 2007, on

\footnotetext{
${ }^{1}$ The expansionary fiscal contraction literature has been much criticized, recently by Guajardo et al. (2014) and Jorda and Taylor (2015).

${ }^{2}$ Or in the behavioural model by Gabaix (2016), with myopia in households' expectations.
} 
French data) and reached the same conclusion: fiscal policy has had positive real effects. The same O. Blanchard published a paper, with D. Leigh, in 2013 in which he acknowledged that "stronger planned fiscal consolidation has been associated with lower growth than expected" because "fiscal multipliers were substantially higher than implicitly assumed". The "implicit" assumption was striking in that it was totally opposite to the results found in the macro literature since the early 2000 s, even before mentioning papers by Creel et al. (2011) and DeLong and Summers (2012), who discussed the non-linear empirical properties of the fiscal multiplier effect relative to the output gap. ${ }^{3}$

Clearly, the academic literature has not had the expected impact: The views of policymakers on fiscal policy have overemphasized the risks of insolvency while under-emphasizing the real effects, in sharp contrast with the literature that had clearly pointed out the risks of fiscal austerity (e.g. Ilzetzki et al. 2013; Brinca et al. 2016). Finally, the idea that under an incomplete monetary union (i.e. without a federal budget) domestic fiscal policies would face the bulk of stabilization requirements while proving ineffective at achieving stabilization was not only contradictory but also wrong. Unfortunately, it spurred the wrong policies. In this respect, the focus on public finances was ill-designed.

\section{The Disastrous View}

Another explanation behind the European imbalances relates to the sudden stop of net capital inflows in the Eurozone periphery, which would have triggered balanceof-payment crises (see e.g. Cesaratto 2013; Baldwin and Giavazzi 2015).

With the advent of the euro in 1999 and free mobility of capital since 1990, crossborder capital flows have increased substantially. Initially, it was perceived as an improvement in macro stability and consistent with the idea that the Eurozone was becoming endogenously optimal. Lagging countries-countries with low investment ratios - accumulated current account deficits that they funded out of increasing credits and capital inflows from leading Eurozone economies. These countries accumulated in return current account surpluses, hence they pursued mercantilist policies. Meanwhile, they found attractive financial opportunities in the least-capitalized economies in the southern and eastern parts of the Eurozone where yields were high due to capital scarcity. High returns were not perceived as risky since, by definition, the exchange-rate risk had vanished. Convergence was therefore expected. However, and finally, a crisis erupted in the peripheral countries. According to the disastrous view, the roots of the crisis had to be found in the malfunctioning of financial markets, i.e. their inability to price risk correctly, which sparked a lack of confidence and outward capital flows, which then provoked a balance-of-payment crisis.

\footnotetext{
${ }^{3}$ The more negative the output gap, the larger the fiscal multiplier.
} 
There are at least two shortcomings of this disastrous view. The first is its "onesize-fits-all" characteristic. It seems to take for granted that all peripheral countries are alike. However, Greece, Portugal, Spain, and Italy did not share the same growth regimes before and after the crisis (see Hein et al. 2016, for a comprehensive comparative analysis). Before the crisis, Greece and Spain could be described as debt-led private-demand boom countries, the former undergoing a boom in private consumption and twin (public and current account) deficits whereas the latter suffered from a housing price bubble. Both countries had high real GDP growth rates, a declining savings ratio and increasing private and public (for Greece) debts. Alternatively, Italy and Portugal could be described as domestic demand-led countries, showing low real growth rates and growing indebtedness but neither a sharp deterioration in their current account balance nor a bubble on the real estate or financial markets. After the crisis, Italy, Portugal, and Spain shifted to an export-led mercantilist growth model, but not Greece. In light of these different characteristics, it is hardly possible that a single explanation for these four countries can emerge. The different sizes of their current account imbalances implied different sensitivities to a sharp reversal of capital flows. Moreover, the balance-of-payment crisis argument neglects the fact that real GDP growth also remained subdued in countries with a current account surplus.

The second shortcoming relates to the timing and structure of the external funding of the peripheral countries: neither characteristic lends much support to the balanceof-payment crisis. Concerning the timing, Fig. 2 shows that foreign private investment in Greece and Portugal increased after the advent of the crisis and decreased only very late. In contrast, the drop was sharp and timely in France. . . although this country did not undergo a so-called balance-of-payment crisis. A timely drop in external funding for Greece is clearly apparent in Fig. 3, however, where "other investments" of the balance of payment are concerned. These "other investments" mostly come from foreign bank credit. Hence the drop looks like a confidence crisis from foreign banks or a crisis of financialization rather than a balance-of-payment crisis per se. Alternatively, it can be viewed as a confidence crisis stemming from the absence of a purchaser of last resort (see e.g. Lavoie 2015), which has contagious effects on the credit supply of private banks.

\section{The Cynical View}

The next explanation behind the surge of macro imbalances in peripheral countries is intrinsically related to the former view as it focuses on the trade imbalances in these countries. In contrast with the disastrous view, however, it does not draw on capital movements but on labor market deficiencies. The cynical view states that peripheral countries ran into the crisis because of a lack of competitiveness (see e.g. Sinn 2014). The adoption of the euro was followed by an increase in nominal wages well above the growth of labor productivity, hence by large increases in unit labor costs (ULC), which deteriorated competitiveness and the trade balance. While ULC decreased in 

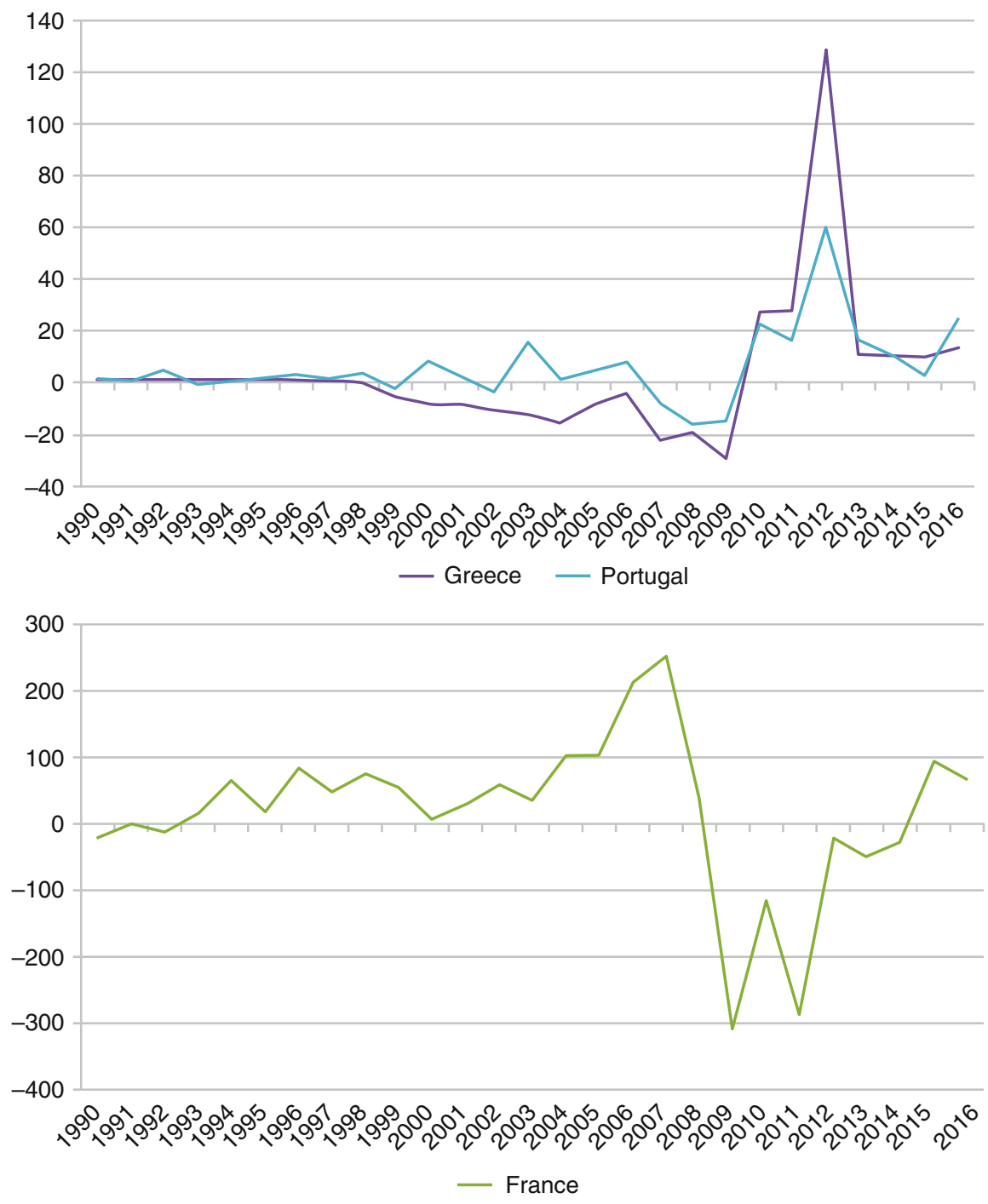

Fig. 2 Net portfolio and foreign direct investments, \$bn. Source: World Bank https://data. worldbank.org/, date of access 20 September 2017

Germany, they increased everywhere else and quite substantially in Ireland, Greece, Italy, Portugal, and Spain. Although it is undeniable that a gap in ULC between Germany, on the one hand, and most other Eurozone countries, on the other hand, occurred after the adoption of the euro, does that mean that the evolution of nominal wages lies at the heart of the crisis in the peripheral countries? We can doubt that for many reasons. 


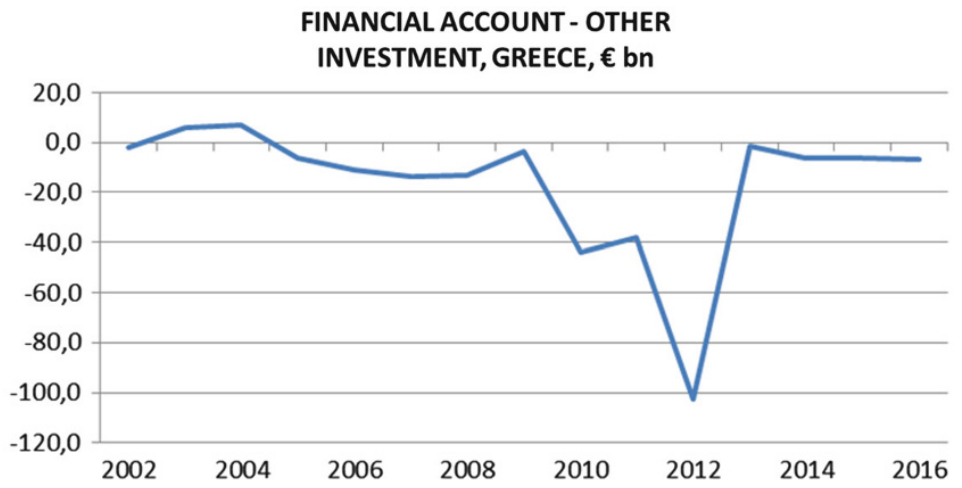

Fig. 3 Financial account, other investment, balance of payment of Greece, €bn. Source: Bank of Greece, https://www.bankofgreece.gr/pages/en/statistics/default.aspx, date of access 20 September 2017

First, trade balance does not depend solely on competitiveness; external and internal demands also matter. Second, nominal wages are not the single determinant of competitiveness. The latter can be divided into two parts: price and non-price competitiveness. While nominal wages have no direct impact on non-price competitiveness, they have an impact on price competitiveness but only jointly with productivity, markups, and labor taxes. Consequently, the influence of nominal wages on price competitiveness, all else being equal, is limited. Third, turning to real, not nominal, ULC gives interesting insights. Since the adoption of the euro, real ULC have been steady in core countries whereas they declined in peripheral countries (Villemot 2017). This is a striking result that proves that wages did not grow excessively in the periphery. On the contrary, part of the value added has shifted from wages to profits. Finally, "competitiveness is not a policy variable" (Gros 2012): in a market economy, supranational institutions and governments do not govern private wages; they can only set or influence public wages. It is clear from the management of the European crisis that the obsession with competitiveness led to policy recommendations to curb nominal wages in order to improve trade balances. The effectiveness of these recommendations is questionable in light of the limited impact of nominal wages. It is even more questionable if only public wages have declined.

Nevertheless, promoters of the cynical view may praise themselves for having fixed the crisis: trade imbalances have receded in the periphery since 2011. Drawing on the former arguments, being sure that these improvements stem from the application of policy recommendations is still an open issue. Turning to the data gives some interesting results. The separation of the respective contributions of exports and imports to the change in the trade balance offers a rough estimate of the impact of competitiveness. Assuming that different countries are highly integrated, hence face similar growth conditions, if the contribution of exports is high, and higher than that of imports, the 


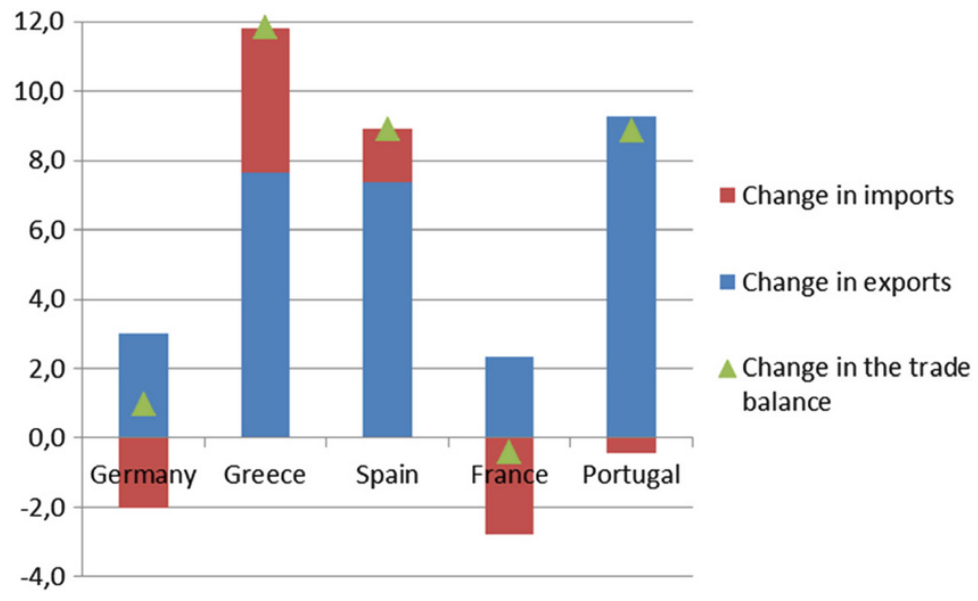

Fig. 4 Change in the trade balance, 2007-2016, in per cent of GDP. Sources: Ameco (https://ec. europa.eu/info/business-economy-euro/indicators-statistics/economic-databases/macro-economicdatabase-ameco/ameco-database_en) and own calculations, date of access 20 September 2017

impact of competitiveness may be strong. Figure 4 shows the contributions to the change in the trade balance for five European countries over a decade. The core countries show quite different patterns: Germany had an improvement in its trade balance due to a higher increase in its exports than imports and France had the complete opposite. The peripheral countries had sharp improvements in their trade balance but also different patterns. All the improvement in Portugal comes from the export side and most of the improvement in Spain comes from the export side whereas only two-thirds of the improvement in Greece comes from the export side while the remaining third comes from the import side. The competitiveness effect seems to have been higher in Portugal than in Spain, and higher in Spain than in Greece.

Now, notwithstanding the roughness of the evaluation-the countries neither face similar growth nor share the same geographical trade structure- the sensitivity towards competitiveness induces some threats that economic prospects pose on future trade balances. The resumption of economic growth in peripheral countries will impinge on imports: In a country like Greece, it may produce a quite substantial deterioration in the trade balance, hence a new headwind on a recovering economy. More importantly, for countries that have gained price competitiveness over the recent years, the prospect of an appreciating euro (notably because of the large current account surplus of the Eurozone vis-à-vis the rest of the world) is definitely unfavorable.

This cynical view, were it true, would thus jeopardize the Eurozone recovery. Remedies to a lasting crisis need to be found outside its boundaries. 


\section{The Comprehensive View}

A comprehensive view of the roots of the European crises can be found in a mix of the former three views. A common drawback of these views is their respective focus on a single determinant and their undervaluation of the impact of the global financial and economic crisis. Against its backdrop, the steep rise in public debts and external debts stemming from large public and current account deficits certainly weakened the peripheral countries more than the core countries. As a matter of fact, the latter countries had either public finances and current accounts in order (e.g. Germany) or limited current account imbalances (e.g. France) before the global crisis. In contrast, other countries had high public deficits and debts before the crisis (e.g. Greece) while some had large current account deficits (e.g. Spain). The emergence of the global financial crisis thus intensified European imbalances, paving the way for a crisis of confidence, a sovereign debt crisis and a competitiveness crisis, with flawed EU governance institutions reluctant to share risks.

In contrast with the three former views, however, the comprehensive view also questions the relevance of policies in the surplus countries. As a matter of fact, the comprehensive narrative involves three interconnected determinants that triggered the European sequel of the global crisis: public finances, current account imbalances, and the output gap, which are not limited to deficits. Indeed, the absence of, for example, a fiscal stimulus in surplus countries may have slowed recovery down domestically but it may also have proved detrimental to deficit countries (Blanchard et al. 2017). It was difficult to reduce the output gap and the current account deficit in the latter countries while they were facing low external demand.

These three interconnected determinants are certainly also essential for dampening the crisis. This view is at the center of Blot et al.'s (2017) and the IMF's (2017) analyses about measuring current account imbalances and how to fix them.

Blot et al. (2017) compute the gap between the structural trade balance (STB) and the trade balance that stabilizes the net international investment position (NIIP) at a desired level expressed as a $\%$ of GDP. ${ }^{4}$ The structural trade balance of a country depends on the output gap of the economy: a negative output gap signals a weak internal demand that diminishes imports. Closing the output gap worsens the trade balance. The structural trade balance also depends on the output gaps of trade partners: if they face a negative output gap, they import less from the country. Closing their output gap then improves the trade balance of the country. Results show that some countries, first and foremost Greece, need to strongly increase their STBs to reach the target. Finland, France, Italy, Portugal, and Spain are also concerned but to a

\footnotetext{
${ }^{4}$ The desired level is given by the threshold, at $-35 \%$ of GDP, of NIIP in the Macro Imbalance Procedure (MIP). The MIP aims to monitor, prevent, and correct the emergence of potentially harmful macroeconomic imbalances that could adversely affect economic stability in a member state. The legal bases of MIP are regulations (EU) 1176/2011 and 1174/2011.
} 
lesser extent. Conversely, Germany and the Netherlands, which already have the highest NIIPs, should reduce their STBs since the current ones imply growing NIIPs.

The IMF (2017) uses the external balance assessment (EBA) model to estimate the relationship between the current account, some fundamental variables (e.g. mediumterm growth potential), and policy variables (e.g. the fiscal stance). Then, the estimated impact of changes in terms of trade and the output gap enables the construction of a cyclically-adjusted measure of the current account balance. Finally, based on desired levels attributed to policy variables, current account norms and current account gaps vis-à-vis the cyclically-adjusted current accounts are calculated. France, Italy, and Spain report weaker gaps than the previous year whereas Germany shows a substantially stronger gap. Moreover, the analysis shows that some countries, e.g. France and Spain, with a negative current account gap (they should improve competitiveness) also have a negative fiscal gap (they should consolidate their budget) while the reverse is true for Germany. Meanwhile, it also shows that the first group of countries, including Italy, has a negative output gap whereas Germany has a positive one.

Both analyses thus point to the symmetry in the current account imbalances between deficit and surplus countries and to the interconnections between fiscal policy, competitiveness, and the output gap. Consequently, symmetry in the management of imbalances through policy coordination would help dampen them. Blot et al. (2017) show that the Eurozone governance is plagued with internal inconsistencies. First, fiscal sustainability requirements mainly rest on fiscal consolidation though the latter produces falls in output, which may in turn reduce trade balances to below (structural) targets. Second, reducing macroeconomic imbalances can be achieved through an improvement in price competitiveness although low inflation makes it harder to curb debt via the Fisherian effect. ${ }^{5}$ Blot et al. argue for cooperation between deficit and surplus countries to stabilize the economy (and reach a zero output gap), reduce imbalances symmetrically, and achieve the targets embedded in the European fiscal rules. They show that non-cooperative solutions are inconsistent with official Eurozone long-term policy targets. Under an asymmetric management of imbalances-only countries with a public or a current account deficit implement policies to curb them while surplus countries neither use fiscal space nor implement reflation policies-simulations with the iAGS model ${ }^{6}$ show that public debts in surplus countries are substantially below $60 \%$ of GDP while the Eurozone inflation rate is well below the $2 \%$ target at a 20 -year horizon. In contrast, simulations of cooperative solutions, i.e. symmetric fiscal and competitiveness adjustments across deficit and surplus countries, are consistent with official long-term policy targets, including the Fiscal Compact. ${ }^{7}$

\footnotetext{
${ }^{5}$ When debt is issued at a fixed interest rate, higher inflation reduces real interest payments and the real value of debt.

${ }^{6}$ See Blot et al. (2014) for a presentation.

${ }^{7}$ Eurozone countries achieve on average a cyclically-adjusted deficit of $0.5 \%$ of GDP.
} 


\section{A Conclusion About Recent Reforms and Proposals}

The story of European macroeconomic imbalances has had many facets that a highly-focused analysis fails to report. In this respect, a comprehensive view that relates the different analyses certainly fits the history of facts and events better.

In light of this comprehensive view, it is possible to discuss the different recent reforms and proposals dealing with future Eurozone economic governance. Here, I focus on two reforms: the Eurozone fiscal stance and the creation of domestic productivity boards; and three proposals: better coordination of economic policies, better risk management in the Eurozone and the adoption of a Eurozone budget.

Since 2016, the European Commission has been computing an aggregate annual fiscal stance for the Eurozone. This reform stems from the adoption of the 2-Pack and was endorsed by the Council in mid-2016. It relates economic stabilization to sustainability issues. Stabilization and sustainability requirements are computed per country, transformed into domestic fiscal stances, and finally aggregated into a Eurozone fiscal stance. Acknowledging the trade-off between output stabilization and public finance sustainability is welcome: Had this trade-off been introduced earlier, fiscal austerity would not have been frontloaded. The real costs stemming from this strategy would have been limited.

The Council recommended the establishment of national productivity boards in September 2016. They analyze developments and policies that can affect productivity and competitiveness at the domestic level, provide independent analyses, and should reinforce policy dialogue. Nevertheless, as they stand, national productivity boards will not ease the symmetric adjustment of prices in the Eurozone because in all likelihood a one-size-fits-all policy will be implemented. Drawing on some kind of "common wisdom" that so-called structural reforms are conducive to higher productivity, all national productivity boards may finally end up promoting the same policies. If they do, the adoption of a mercantilist stand in all countries alike will increase the current account surplus of the Eurozone vis-à-vis the rest of the world. This will make the Eurozone more vulnerable to external shocks and lead to the appreciation of the euro.

In light of the comprehensive view, separate reforms dedicated either to budget issues or to structural divergences will not help achieve the much-desired two-tier coordination long advocated in the iAGS reports (e.g. OFCE-ECLM-IMK-AK 2016): fiscal coordination with backloading policies and coordination on symmetric structural reforms. Fiscal coordination should aim to use the flexibility of the SGP to minimize the social cost of fiscal consolidation. Symmetric structural reforms, via more or less generous reforms depending on the sign and size of current account imbalances, should help stabilize divergence across the member states and limit the suboptimality of the euro. Despite its Pareto-improving property, ${ }^{8}$ this path of reform is absent from the political agenda.

\footnotetext{
${ }^{8}$ The two-tier coordination can be viewed as a Pareto-improving equilibrium. As a matter of fact, the less cooperation on one-tier, the more stimulus required on the other to counterbalance the social cost and/or the lack of inflation, and the higher the spillovers on partner countries.
} 
Recently, two proposals have emerged in the political agenda. The first path of reform, embodied by former German minister W. Schäuble in his testimony to the Council, is based on two principles. The first requires the enforcement of rules. To achieve this, one needs to simplify the system of rules and focus on the nominal deficit rule and on the rule of return of the public debt to GDP ratio to its $60 \%$ threshold. Moreover, the application of rules should be monitored by the European Stability Mechanism without going through a political process in the Council. By doing so, the rules would be applied more rigorously. The second principle relates to financial risks that threaten cohesion between member states. Given the ECB's large purchases of public debts and the zero risk assigned to them by banks, in line with prudential regulation, the risk of holding an Italian public debt, for example, is artificially made similar to that of holding a German debt. The perverse effect underlying this (possible) undervaluation of risk is to encourage postponing public debt reduction. To bring this situation to an end, market discipline is invoked: the government whose default risk is perceived to be higher should suffer an increase in its risk premium. This would encourage governments to actually reduce their debts.

This path of reform has at least two imperfections. The first is to see a state emerge as a reference for the market. This country will issue by default the only safe asset of the Eurozone. This will increase the divergence of credit costs within the zone, with the referring state borrowing at a lower interest rate than the others. Resorting to market discipline also imposes a strong dependence of states and banks on financial volatility. Ten years after the beginning of a crisis that saw markets unable to properly assess risks, this is an amazing argument.

The second path of reform focuses on the management of economic crises. This management would involve political coordination in sharp contrast with market discipline. The recent situation has shown that the Eurozone does not have an automatic mechanism to boost the economy after a crisis. The French president, in September 2017 at the Sorbonne, defended the adoption of a Eurozone budget to provide investment, emergency financial assistance, and crisis absorption capacity, to be placed under the responsibility of a minister of economy and finance. Other proposals, such as that of the Italian government, advocate that the Eurozone's ministry of economy and finance provide European public goods; for example, transnational public investments or spending on ecological transition. While this path of reform gives some substance to a better management of the interactions between fiscal policy and the output gap, it is silent on current account imbalances.

On 6 December 2017, the Commission set out its proposals of reform with a balanced focus on market discipline and budget integration. The Commission requires the integration of the fiscal rule on the cyclically adjusted deficit (stemming from the Fiscal Compact of 2012) into EU legal framework. This initiative would unfetter the Commission from the intergovernmental dimension of the Fiscal Compact and permit it to resume control over all the budgetary rules. It also shows its attachment to the rules and their stricter application, although it does not demonstrate that these rules have been effective so far. The Commission is also proposing the transformation of the ESM into a European Monetary Fund (EMF), no doubt also to 
avoid an intergovernmental mechanism-the ESM-which reduces its power of initiative and control. The EMF would make adopting a preventive component of budget crises possible.

The Commission proposes the adoption of a stabilization fiscal capacity within the framework of the European budget. The latter would thus share a new function, macroeconomic stability, with the current ones: sustainable growth, competitiveness, cohesion and security. This fiscal capacity would involve a support for public investment in the event of a crisis.

This proposal raises two remarks. On the one hand, in its current form, the EU budget is balanced and therefore irreconcilable with macroeconomic stabilization (which it was not responsible for until then). To be effective, fiscal capacity should be associated with a debt capacity, which has not been mentioned so far. On the other hand, the size of the EU budget is limited. If this limit persists, and given that the UK contribution will vanish after Brexit, a new budget function will question the spending allocation: which ones will decrease to give room to maneuver in the new budgetary capacity?

What might be the implications of these reform proposals on the development of the Eurozone and the EU? In light of the recent contribution by Benigno and Fornaro (2018), the interactions between economic fluctuations, long-run growth, and stabilization policies require a common theoretical framework to offer guidance to policymakers. Clearly, a Keynesian framework, with subdued aggregate demand and unemployment, associated with subdued investment in innovations, can offer this type of guidance. In this framework, innovations can foster productivity growth, hence they can sustain aggregate demand. Moreover, high demand can generate investment, hence higher productivity growth. Consequently, supply-side and demand-side are complementary to enhance a sustainable growth environment where fluctuations are dampened and long-run growth is stimulated.

The current agenda of reforms in the Eurozone ${ }^{9}$ may have a limited impact in this respect, for at least four reasons. First, it is not comprehensive enough. Steps to manage macro imbalances symmetrically are absent from mainstream reform agendas. Second, the outcome of these projects is not for tomorrow as the horizon to reach an agreement on the various aspects of reforms (Eurozone budget, EMF, domestic fiscal rules) could extend to 2025. Unfortunately for the Eurozone, the status quo could last and macro imbalances and economic fluctuations could remain. This may lead policymakers to continue keeping an eye on the short term rather than on the long term. Third, the margins for maneuver embedded in a Eurozone budget (if it were adopted) would remain limited and ill-designed for the required sharp and positive public impetus for investment that would extract the Eurozone from a stagnation trap à la Benigno and Fornaro. Fourth, while the EU has enriched the

\footnotetext{
${ }^{9}$ I do not have sufficient space to develop the position of the 14 Franco-German economists (see Bénassy-Quéré et al. 2018) who focus on the financial and fiscal stability of the Eurozone. They borrow from (or inspire) both paths of reforms that I referred to previously. Their long-term view of the Eurozone is limited to the resilience of the area, i.e. its ability to cope with future macroeconomic and financial shocks.
} 
set of convergence indicators to social ones with the adoption of the European Pillar of Social Rights, there remains a contradiction between the growing number of EU objectives in the European Semester and the constant number of tools and financial means to fulfil them. The achievement of a more equal Eurozone requires more than the multiplicity of "productivity boards" without clear cooperation tools and a vision of structural reforms that continues to aim for flexibility and competition, even though both have already reached high levels in Europe. To promote growth that cares for the future, the EU should turn away from the recipes of the past (an accounting approach of fiscal policy and market-oriented structural reforms), which have not been helpful for fixing the European crisis. In contrast, EU governments should invest in the future and incentivize innovations via tax and fiscal policies.

\section{References}

Baldwin, R., \& Giavazzi, F. (2015, September 7), Towards a consensus on the causes of the EZ crisis. Voxeu.org, https://voxeu.org/article/towards-consensus-causes-ez-crisis

Bénassy-Quéré, A. et al. (2018). Reconciling risk sharing with market discipline: A constructive approach to euro area reform. CEPR Policy Insight, 91.

Benigno, G., \& Fornaro, L. (2018). Stagnation traps. Review of Economic Studies, 85(3), $1425-1470$.

Blanchard, O., \& Leigh, D. (2013). Growth forecast errors and fiscal multipliers. American Economic Review, 103(3), 117-120.

Blanchard, O., \& Perotti, R. (2002). An empirical characterization of the dynamic effects of changes in government spending and taxes on output. Quarterly Journal of Economics, 117(4), $1329-1368$

Blanchard, O., Erceg, C. J., \& Lindé, J. (2017). Jump-starting the Eurozone recovery: Would a rise in core fiscal spending help the periphery. In M. Eichenbaum \& J. A. Parker (Eds.), NBER macroeconomics annual 2016 (Vol. 31, pp. 103-182).

Blot, C., Cochard, M., Creel, J., Ducoudré, B., Schweisguth, D., \& Timbeau, X. (2014). Fiscal consolidation, public debt and output dynamics in the Eurozone: Lessons from a simple model with time-varying fiscal multipliers. Revue d'économie politique, 124(6), 953-989.

Blot, C., Creel, J., Ducoudré, B., Timbeau, X., \& Villemot, S. (2017). Dealing with external imbalances and public debt objectives in the Eurozone: A dilemma? Presented at Workshop "External imbalances: causes, consequences and rebalancing", October 14, University of Lille1, http://ermees.fr/wp-content/uploads/2017/02/21_anuscript_Blot.pdf

Brinca, P., Holter, H. A., Krusell, P., \& Malafry, L. (2016). Fiscal multipliers in the 21st century. Journal of Monetary Economics, 77, 53-69.

Cesaratto, S. (2013). The implications of TARGET2 in the European balance of payments crisis and beyond. European Journal of Economics and Economic Policy: Intervention, 10(3), 359-382.

Creel, J., \& Sterdyniak, H. (1998). Du bon usage des politiques monétaire et budgétaire en Europe. Revue d'économie financière, 45, 167-196.

Creel, J., Monperrus-Veroni, P., \& Saraceno, F. (2007). Politique budgétaire discrétionnaire en France. Les effets à court et à long terme. Revue économique, 58(5), 1035-1053.

Creel, J., Heyer, É., \& Plane, M. (2011). Petit précis de politique budgétaire par tous les temps. Les multiplicateurs budgétaires au cours du cycle. Revue de l'OFCE, O(1), 61-88.

DeLong, J. B., \& Summers, L. H. (2012). Fiscal policy in a depressed economy. Brookings Papers on Economic Activity, 43(1), 233-297. 
Gabaix, X. (2016, December). A behavioral new Keynesian model (NBER working paper no. 22954).

Giavazzi, F., \& Pagano, M. (1990). Can severe fiscal contractions be expansionary? Tales of two small European countries. In O. Blanchard \& S. Fischer (Eds.), NBER macroeconomics annual (pp. 75-111). Cambridge, MA: MIT Press.

Gros, D. (2012, April). Macroeconomic imbalances in the Eurozone: Symptom or cause of the crisis? CEPS Policy Brief, 266.

Guajardo, J., Leigh, D., \& Pescatori, A. (2014). Expansionary austerity? International evidence. Journal of the European Economic Association, 12(4), 949-968.

Hein, E., Detzer, D., \& Dodig, N. (Eds.). (2016). Financialisation and the financial and economic crises. Cheltenham: Edward Elgar.

Ilzetzki, E., Mendoza, E. G., \& Vegh, C. A. (2013). How big (small?) are fiscal multipliers? Journal of Monetary Economics, 60(2), 239-254.

IMF. (2017, July). 2017 external sector report. IMF Policy Paper.

Jorda, O., \& Taylor, A. M. (2015). The time for austerity: Estimating the average treatment effect of fiscal policy. Economic Journal, 126(590), 219-255.

Lane, P. R. (2012). The European sovereign debt crisis. Journal of Economic Perspectives, 26(3), $49-67$.

Lavoie, M. (2015). The Eurozone crisis: A balance-of-payments problem or a crisis due to a flawed monetary design? A reply to Sergio Cesaratto. International Journal of Political Economy, 44(2), 157-160.

OFCE-ECLM-IMK-AK. (2016, November). The elusive recovery. iAGS 2017, independent Annual Growth Survey report.

Sinn, H.-W. (2014). Austerity, growth and inflation: Remarks on the Eurozone's unresolved competitiveness problem. World Economics, 37(1), 1-13.

Villemot, S. (2017). Les déséquilibres des balances courantes dans la zone Euro: comment les résorber?, in OFCE, L'économie Européenne 2017, Repères, Paris: La Découverte.

Wyplosz, C. (1997). EMU: Why and how it might happen. Journal of Economic Perspectives, 11(4), 3-22.

Open Access This chapter is licensed under the terms of the Creative Commons Attribution 4.0 International License (http://creativecommons.org/licenses/by/4.0/), which permits use, sharing, adaptation, distribution and reproduction in any medium or format, as long as you give appropriate credit to the original author(s) and the source, provide a link to the Creative Commons licence and indicate if changes were made.

The images or other third party material in this chapter are included in the chapter's Creative Commons licence, unless indicated otherwise in a credit line to the material. If material is not included in the chapter's Creative Commons licence and your intended use is not permitted by statutory regulation or exceeds the permitted use, you will need to obtain permission directly from the copyright holder.



